\title{
Can Leguminous Cover Crops Partially Replace Nitrogen Fertilization in Mississippi Delta Cotton Production?
}

\author{
Robert M. Zablotowicz, ${ }^{1}$ Krishna N. Reddy, ${ }^{1}$ L. Jason Krutz, ${ }^{1}$ R. Earl Gordon, ${ }^{1}$ \\ Ryan E. Jackson, ${ }^{2}$ and Leslie D. Price ${ }^{2}$ \\ ${ }^{1}$ Crop Production Systems Research Unit, USDA-Agricultural Research Service, 141 Experiment Station Road, Stoneville, \\ MS 38776, USA \\ ${ }^{2}$ Southern Insect Management Research Unit, USDA-Agricultural Research Service, 141 Experiment Station Road, Stoneville, \\ MS 38776, USA \\ Correspondence should be addressed to Krishna N. Reddy, krishna.reddy@ars.usda.gov \\ Received 26 October 2010; Accepted 13 January 2011 \\ Academic Editor: M. Tejada
}

Copyright ( $) 2011$ Robert M. Zablotowicz et al. This is an open access article distributed under the Creative Commons Attribution License, which permits unrestricted use, distribution, and reproduction in any medium, provided the original work is properly cited.

Petroleum prices impact cotton nitrogen (N) fertilization cost. A field study was conducted from 2005 to 2007 to assess the interactions of cover crop (none, Austrian winter pea (Pisum sativum spp. arvense) or hairy vetch (Vicia villosa Roth)) and $\mathrm{N}$ fertilization $(0,67$ or $134 \mathrm{~kg} \mathrm{~N} /$ ha applied at planting) on $\mathrm{N}$ availability and cotton yield under reduced-tillage management. Nitrogen content in desiccated residues averaged 49,220, and $183 \mathrm{~kg} \mathrm{~N} /$ ha, in no cover crop, Austrian winter pea, and hairy vetch, respectively. Seventy percent of $\mathrm{N}$ in the above ground cover crop was derived from biological $\mathrm{N}$ fixation. In 2005, cover crops decreased cotton yield, while fertilizer $\mathrm{N}$ had no effect. In 2006, cover crops did not affect yield, but yield was positively correlated with $\mathrm{N}$ rate. In 2007, in no $\mathrm{N}$ plots, cotton yields were $65 \%$ higher in cover crops than in no cover crop. However, yield from $\mathrm{N}$ fertilized cover crop plots were similar to $\mathrm{N}$ fertilized no cover plots. These results indicate that leguminous cover crops can provide over $150 \mathrm{~kg} \mathrm{~N} / \mathrm{ha}$, but this $\mathrm{N}$ may not be as effective as fertilizer $\mathrm{N}$ for lack of synchronization between cotton $\mathrm{N}$ requirements and $\mathrm{N}$ release from residues.

\section{Introduction}

Cotton (Gossypium hirsutum L.) is a major row crop in the Mississippi Delta region of the southern US, and its production under reduced and no-tillage systems has increased in this region with the introduction of glyphosate-resistant varieties. Sustainable, low-input cropping systems, that is, reduced tillage, no-tillage, and fall seeded leguminous cover crops, are favored by economic pressures including energy, fertilizer, and agrochemical costs. Moreover, crop production systems that combine minimum and (or) reduced tillage with fall seeded cover crops offer environmental advantages such as improved soil tilth, weed suppression, reduced erosion, and off-site agrochemical transport [1].

In some areas of the southern US, high residue cereal cover crops, such as rye, were successfully integrated into cotton cropping systems. Cereal cover crops, however, require additional $\mathrm{N}$ for adequate plant residue production which may lead to $\mathrm{N}$ immobilization and reduced cotton yield [2]. However, as legumes can provide additional $\mathrm{N}$ for the following crop, leguminous cover crops may provide a source of sustainable $\mathrm{N}$ input. Mississippi Delta field trials indicate some benefits of a hairy vetch cover crop in corn production [3], as did similar trials in Missouri [4]. Leguminous cover crops provide an additional benefit of $\mathrm{N}$ fixation in the fallow period which can supply $\mathrm{N}$ to the successive crop $[5,6]$. Under these Australian conditions, vetches produced an average of $225 \mathrm{~kg} \mathrm{~N} / \mathrm{ha}$, and replaced over $60 \%$ of the $\mathrm{N}$ fertilizer requirement for optimum cotton production.

Profitable cotton production will require alteration of $\mathrm{N}$ inputs under alternative tillage and cover crop systems [7]. In the sandy soils of the Southeastern coastal plains, a leguminous cover crop was not as cost effective as cereal cover crops [8]. The objective of this 3-year field study conducted 
from 2005 to 2007 on a Dundee silt loam was to assess the interactions of leguminous cover crops (none, Austrian winter pea (Pisum sativum spp. arvense) or hairy vetch (Vicia villosa Roth)), and $\mathrm{N}$ fertilization rate $(0,67$ or $134 \mathrm{~kg} \mathrm{~N} / \mathrm{ha}$ applied at planting) on $\mathrm{N}$ availability and cotton yield under reduced-tillage management.

\section{Materials and Methods}

2.1. Cover Crop and Cotton Management. A field study was conducted from 2004 through 2007 at the USDAARS Crop Production Systems Research farm, Stoneville, MS $\left(33^{\circ} 26^{\prime} \mathrm{N}, 90^{\circ} 55^{\prime} \mathrm{W}\right)$. The soil was a Dundee silt loam (fine-silty mixed, thermic Aeric Ochraqualf) with $\mathrm{pH}$ 6.3, $9.0 \mathrm{~g} \mathrm{~kg}^{-1}$ organic carbon, a CEC of $15 \mathrm{cmol}_{\mathrm{c}} \mathrm{kg}^{-1}$ ) soil, and soil textural fractions of $26 \%$ sand, 55\% silt, and 19\% clay. Prior to the present study, the experimental area was under corn production. Field preparation consisted of disking, subsoiling, disking, and bedding in the fall of 2004. The land was not tilled in subsequent years, but the raised seedbeds were refurbished each fall after harvest with no additional tillage operations to maintain a reduced tillage system. The raised seedbeds ensured adequate drainage in early spring, helping to prevent planting delays and enabling furrow irrigation during the growing season.

Cover crop treatments consisted of Austrian winter pea (Pisum sativum spp. arvense), hairy vetch (Vicia villosa Roth), and no cover crop. Cover crops were drilled in 19$\mathrm{cm}$ wide rows using a grain drill (Deere and Co., Moline, IL, USA) at a seed rate of $30 \mathrm{~kg} / \mathrm{ha}$ in mid-October of 2004, 2005, and 2006. Cover crops were desiccated with paraquat at $1.1 \mathrm{~kg}$ ai $/$ ha about $2 \mathrm{wk}$ prior to cotton planting. At desiccation, Austrian winter pea was about $46-$ to $61-\mathrm{cm}$ tall and hairy vetch was about $30-$ to $53-\mathrm{cm}$ tall and both were at early flowering stage. No cover crop plots were also treated with paraquat at $1.1 \mathrm{~kg}$ ai/ha to kill existing vegetation. Glyphosate-resistant cotton cultivar "DP434RR" was planted on April 25, 2005, April 28, 2006, and April 30, 2007 using a MaxEmerge 2 planter (Deere and Co., Moline, IL, USA) in $102-\mathrm{cm}$ rows at 120,000 seeds/ha directly into desiccated plant residue. Nitrogen fertilizer treatments included 0, 67, and $134 \mathrm{~kg} \mathrm{~N} / \mathrm{ha}$. The commercial liquid formulation of urea and ammonium nitrate (N-SOL 32, Mississippi Chemical Corporation, Yazoo City, MS, USA) was applied at cotton planting.

Cotton was maintained weed-free using only postemergence herbicide programs. Glyphosate at $0.84 \mathrm{~kg}$ ae/ha was applied postemergence, over-the-top twice at 4 and $6 \mathrm{wk}$ after planting cotton. A third glyphosate application at $0.84 \mathrm{~kg} / \mathrm{ha}$ was made as postdirected to base of the crop plant at $9 \mathrm{wk}$ after planting. Glyphosate applications were common to all treatments. Potash application and insect control programs were standard for cotton production [9]. Cotton was furrow irrigated on an as-needed basis: five times in 2005, three times in 2006, and eight times in 2007. Cotton from all eight rows of each plot was harvested once with a spindle picker on September 19, 2005, September 11, 2006, October 10, 2007, and seed cotton yield was reported.
2.2. Experimental Design and Statistical Analysis. The experiment was conducted in a split-plot arrangement of treatments in a randomized complete block design with cover crop (Austrian winter pea, hairy vetch, and no cover crop) as main plot and $\mathrm{N}$ level $(0,67$, and $134 \mathrm{~kg} \mathrm{~N} / \mathrm{ha})$ as the subplot with four replications. Each treatment consisted of eight rows spaced $102 \mathrm{~cm}$ apart and $25.9 \mathrm{~m}$ long. The identity of each treatment was maintained by assigning the same treatment to the same plot in all three years. Data were subjected to analysis of variance using PROC GLM (Statistical Analysis Systems, Statistical Analysis Systems Institute, Cary, NC) and treatment means were separated at the 5\% level of significance using Fisher's protected LSD test.

2.3. Soil, Cotton, and Cover Crop Residue Sampling. Estimates of plant residues on the soil surface were determined the day before herbicide desiccation and at planting (before $\mathrm{N}$ fertilization) in all three years, and 29 and 20 days after planting in 2005 and 2006, respectively. Insufficient residues were present for a postplanting sampling in 2007. Three $0.1-\mathrm{m}^{2}$ quadrants were randomly selected from the center four rows of each plot, all vegetation was clipped at the soil surface, combined, oven dried, and weighed. Following removal of surface vegetative residues two 0 - to $5-\mathrm{cm}$ soil cores were removed using a $7.5-\mathrm{cm}$ wide probe from each of these three quadrants. Soils were passed through a $2-\mathrm{mm}$ sieve and used fresh for enzymatic activity or air dried for determination of chemical properties. Fully expanded cotton leaves (about 50 per plot) were collected from cotton during early to mid-boll filling for $\mathrm{N}$ content determination. Cover crop residues and cotton leaf samples were oven dried at $60^{\circ} \mathrm{C}$ for 48 to $96 \mathrm{~h}$, depending on the mass of the vegetation collected.

2.4. Plant Analysis. Cover crop and cotton leaf samples were analyzed for $\mathrm{N}$ content using a Flash EA 1112 elemental analyzer (CE Elantech, Lakewood, NJ, USA). Prior to analysis, previously dried samples were dried at $60^{\circ} \mathrm{C}$ overnight and duplicate samples ( $\sim$ to $8 \mathrm{mg}$ ) were analyzed for each plot.

Delta ${ }^{15} \mathrm{~N}$ abundance was evaluated based on the the ratio of ${ }^{15} \mathrm{~N} /{ }^{14} \mathrm{~N}$ ratio [10]. Dried ground samples $(1 \mathrm{mg})$ were analyzed with a Thermo Finnigan Delta Plus Advantage Mass Spectrometer with a Finnigan ConFlo III and Isomass Elemetal Analyzer (Bremen, Germany) that used a Costech ECS4010 using elemental combustion system equipped with an autosampler, using Isodat software version 2.38 to calculate delta values.

The proportion of $\mathrm{N}$ in Austrian winter pea and hairy vetch estimated to arise from $\mathrm{N}$ fixation (\%Ndfa) was calculated based on the equation of Peoples et al. [11] and Rochester and Peoples [5]:

$$
\% \mathrm{Ndfa}=100 \frac{(X-Y)}{(X-B)}
$$

where $X$ is the ${ }^{15} \mathrm{~N}$ content of a non $\mathrm{N}_{2}$-fixing, nonlegume, $Y$ is the ${ }^{15} \mathrm{~N}$ content of the legume, and $B$ is the ${ }^{15} \mathrm{~N}$ content of the shoot when totally dependent on $\mathrm{N}_{2}$ fixation for growth, 
$(-0.47)$ from Rochester and Peoples [5]. Total estimates of $\mathrm{N}_{2}$ fixed were than calculated as follows:

$$
\text { Amount of } \mathrm{N}_{2} \text { fixed }=(\text { Legume } \mathrm{N} \times \% \mathrm{~N}) \times(\% \mathrm{Ndfa}) \text {. }
$$

2.5. Soil Chemical Analysis. Chemical analysis was conducted on air-dried soil that was passed through a $2 \mathrm{~mm}$ sieve and uniformly milled in a Wiley mill. Soil $\mathrm{pH}$ was determined in a $0.01 \mathrm{M} \mathrm{CaCl}_{2}$ soil suspension $(2: 1)$. Total organic carbon (TOC) and Total N Content (TNC) were determined on duplicate samples using a Flash EA 1112 elemental analyzer (CE Elantech, Lakewood, NJ, USA). For nitrate-N analysis, soil ( $2 \mathrm{~g}$ ) was extracted in $10 \mathrm{~mL} 0.1 \mathrm{M} \mathrm{KCl}$, for $1 \mathrm{~h}$, clarified by centrifugation, and determined colorimetrically [12].

2.6. Soil Enzymatic Activity. Soil hydrolytic activity was evaluated as an indicator of microbial activity, using fluorescein diacetate (FDA). Assays were conducted on freshly collected soil that has been sieved using methodology reported elsewhere [13-15]. Assays were conducted in triplicate corrected for a no substrate control and reported on an oven dry weight equivalent basis.

\section{Results and Discussion}

3.1. Cover Crop Biomass Production, $N$ Content, ${ }^{15} N$ Abundance and $N$ Fixation Estimates. Winter vegetation (weed) biomass present in no cover crop plots ranged from $1969 \mathrm{~kg} / \mathrm{ha}$ to $5062 \mathrm{~kg} / \mathrm{ha}$ prior to herbicide desiccation (Table 1). Plots seeded with Austrian winter pea and hairy vetch produced a similar biomass in 2005 and 2007 ranging from 7479 and $9025 \mathrm{~kg} / \mathrm{ha}$, respectively. However, in 2006, Austrian winter pea yielded about $40 \%$ higher than hairy vetch. The highest level of cover crop residues remaining on the surface (6485 and $7286 \mathrm{~kg} / \mathrm{ha}$ in hairy vetch and Austrian winter pea, resp.) was present at planting in 2005 compared to 2006 or 2007. However, cotton was planted only four days after cover crop desiccation in 2005, compared to 23 days in 2006 and 21 days in 2007 allowing more time for decomposition of crop residues. Both legumes consistently yielded appreciable biomass. As in many field trials conducted elsewhere, the biomass produced by Austrian winter pea and/or hairy vetch yielded over $20 \%$ or more biomass than annual weeds under no-tillage $[8,15]$.

The $\mathrm{N}$ content present in Austrian winter pea and hairy vetch residues prior to desiccation was lowest $(2.25$ and $1.75 \%$ ) in 2005 with a significantly higher $\mathrm{N}$ level in Austrian winter pea compared to hairy vetch. Thereafter, a similar level of $\mathrm{N}$ concentration was found in the cover crop residues (2.58 to $3.13 \%$ ) in 2006, and 2007. Nitrogen content of native vegetation by comparison was $1.04,0.86$ and $1.68 \%$ in 2005,2006 , and 2007 , respectively. Total $\mathrm{N}$ present in natural winter vegetation ranged from 36 to $86 \mathrm{~kg} \mathrm{ha}^{-1}$ prior to desiccation (Figure 1). In Austrian winter pea residues, the total $\mathrm{N}$ present on the soil surface ranged from 170 to $255 \mathrm{~kg} / \mathrm{ha}$, and 133 to $225 \mathrm{~kg} / \mathrm{ha}$ in hairy vetch residues (Figure 1). The total amount of Austrian winter pea and hairy vetch biomass and biomass $\mathrm{N}$ produced in these Mississippi field trials is much higher than the 84 and $101 \mathrm{~kg} \mathrm{~N} / \mathrm{ha}$, respectively in field trials conducted in the Southeastern U.S. [8]. The studies conducted by Schomberg et al. [8] were on sandy coastal plains soils of lower fertility than the rich alluvial silt loam soils of the Mississippi Delta and these differences in fertility promoted vigorous cover crop biomass production.

The depletion of $\mathrm{N}$ from residues on the soil surface followed the pattern of the degradation of vegetative residues with about $75 \%$ of the initial $\mathrm{N}$ present in the legume residues at planting in 2005, while 36 to $56 \%$ was present in the legume residues at planting in 2006 and 2007 (Figure 1). In 2005, cotton was planted $4 \mathrm{~d}$ after cover crop desiccation, while in 2006 and 2007 cotton was planted 23 and $21 \mathrm{~d}$, respectively, following desiccation. Thus, greater biomass $\mathrm{N}$ remained on the soil surface initially in 2005. In 2005, 22 to $29 \%$ of the $\mathrm{N}$ was present in legume residues one month after planting, while less than 5 to $14 \%$ was present 20 days after planting in 2006. This indicates a rapid release of the foliar $\mathrm{N}$ content. Volatile loss of ammonia has been suggested to occur during the decomposition of a lentil (Lens culinaris Medik) green manure with about 8 to $14 \%$ loss in 14 days under controlled laboratory conditions [16]. These studies were conducted under reduced-tillage conditions and environmental conditions may have been favorable for volatilization loss. The average maximum air temperatures during April for Stoneville is $24^{\circ} \mathrm{C}$ [17] with the surface residues prone to rapid drying. It is possible that a significant amount of $\mathrm{N}$ in plant residues may have been lost by volatilization. If the cover crop had been incorporated into the soil prior to planting cotton; there may have been more $\mathrm{N}$ available for the cotton, however, this would have eliminated the benefits of conservation tillage management.

Over the three-year study, the $\delta \mathrm{N}^{15}$ values in leguminous cover crop residues prior to desiccation (0.64 to 1.33 ) were similar between Austrian winter pea and hairy vetch, which was significantly lower than native winter vegetation present in no cover crop plots (Table 2). Using the methodology of Rochester and Peoples [5], a 68 to $77 \%$ of the shoot $\mathrm{N}$ content was derived from $\mathrm{N}_{2}$ fixation (\%Ndfa) in Austrian winter pea and 66 to $69 \%$ in hairy vetch (data not shown). Estimates of $\mathrm{N}$ fixation in Austrian winter pea ranged from 92 to $178 \mathrm{~kg}$ of shoot N/ha and 67 to $165 \mathrm{~kg}$ of shoot N/ha in hairy vetch (Table 3 ). The lowest $\mathrm{N}$ fixed was in the initial year of the study, and Austrian winter pea fixed a greater amount of $\mathrm{N}$ when compared to hairy vetch in 2005 and 2006. There was no significant effect of $\mathrm{N}$ fertilization level on $\delta \mathrm{N}^{15}$ values, \% shoot $\mathrm{N}$ fixed (TFDA), or total $\mathrm{N}$ fixed. These are estimates of $\mathrm{N}_{2}$ fixation based solely upon shoot $\mathrm{N}$ content the contribution of $\mathrm{N}_{2}$ fixation from below ground roots, nodules and exudation may represent from $10 \%$ to $40 \%$ of the above ground $\mathrm{N}_{2}$ fixation estimates [5].

3.2. Effects of Cover Crop Management on Soil Properties. In the first spring (2005) sampling, FDA-hydrolytic activity in nocover crop soils was 25 to $30 \%$ higher compared to soil from plots managed with either cover crop (Table 4). However, one month following cover crop desiccation in 
TABLE 1: Effect of cover crop on plant residues remaining on soil surface at various times in 2005, 2006 and 2007.

\begin{tabular}{lccc}
\hline Cover crop & & $\begin{array}{c}\text { Plant residue dry weight, kg/ha } \\
\text { Sampling date }\end{array}$ \\
\hline & April 15, 2005 & April 24, 2005 & May 23, 2005 \\
None & $3865 \mathrm{~b}$ & $2584 \mathrm{~b}$ & $7179 \mathrm{~b}$ \\
Austrian winter pea & $7479 \mathrm{a}$ & $7286 \mathrm{a}$ & $2228 \mathrm{a}$ \\
Hairy vetch & $7532 \mathrm{a}$ & $6485 \mathrm{a}$ & May 16, 2006 \\
& April 10, 2006 & April 27, 2006 & Not detectable \\
None & $1969 \mathrm{c}$ & $1246 \mathrm{~b}$ & $2056 \mathrm{a}$ \\
Austrian winter pea & $5704 \mathrm{a}$ & $3737 \mathrm{a}$ & $751 \mathrm{~b}$ \\
Hairy vetch & $4070 \mathrm{~b}$ & $3336 \mathrm{a}$ & April 30, 2007 \\
& April 03, 2007 & $1474 \mathrm{c}$ & $3368 \mathrm{~b}$ \\
None & $5062 \mathrm{~b}$ & $4193 \mathrm{a}$ \\
Austrian winter pea & $9025 \mathrm{a}$ & $8724 \mathrm{a}$ & \\
Hairy vetch & & & \\
\hline
\end{tabular}

${ }^{a}$ Means followed by the same letter within a column for the same sampling date do not differ at the $95 \%$ confidence level.

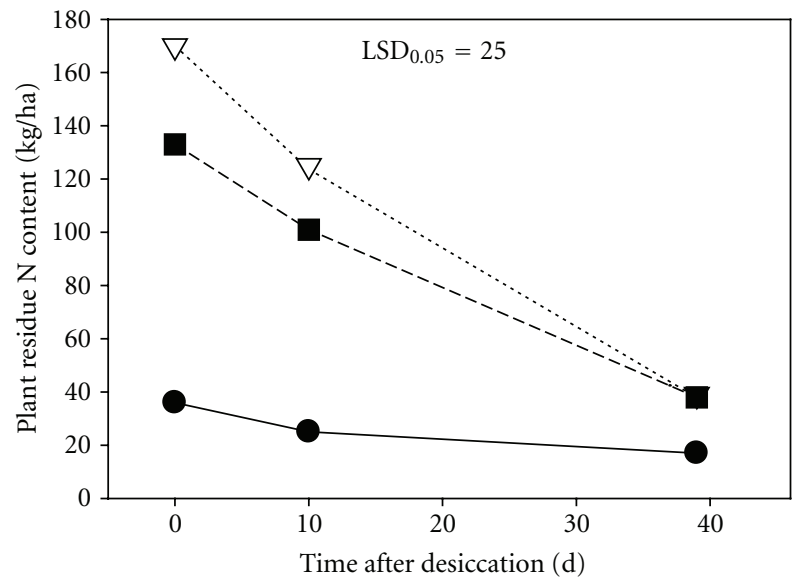

(a)

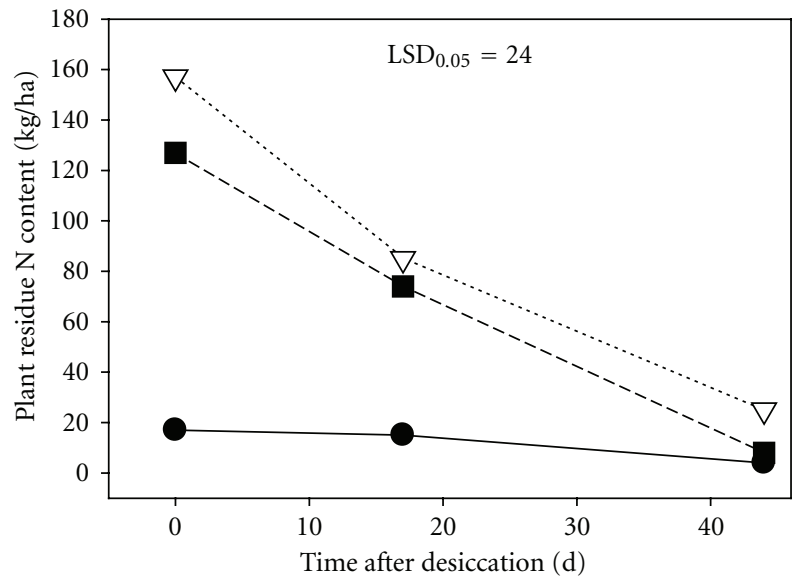

(b)

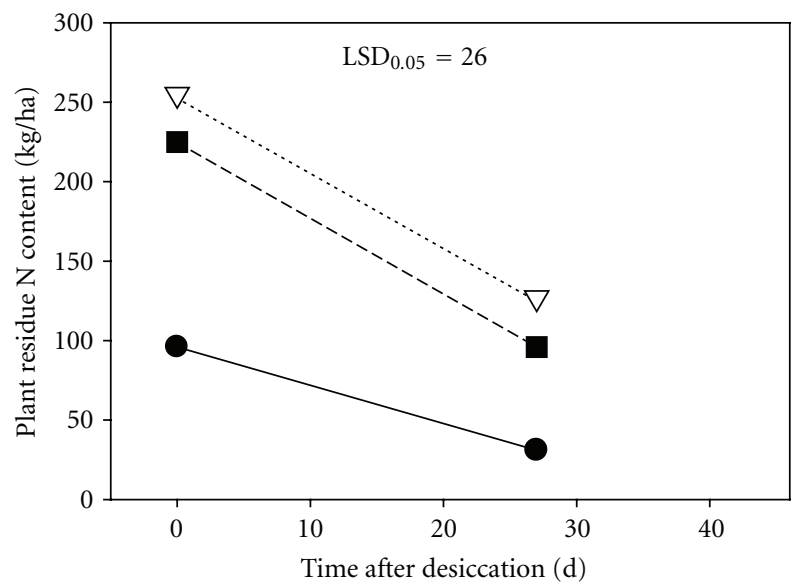

(c)

FIGURE 1: Nitrogen content of plant residues as affected by cover crop, circles no cover crop, triangles Austrian winter pea, squares hairy vetch, $(\mathrm{a})=2005,(\mathrm{~b})=2006$, and $(\mathrm{c})=2007$. 


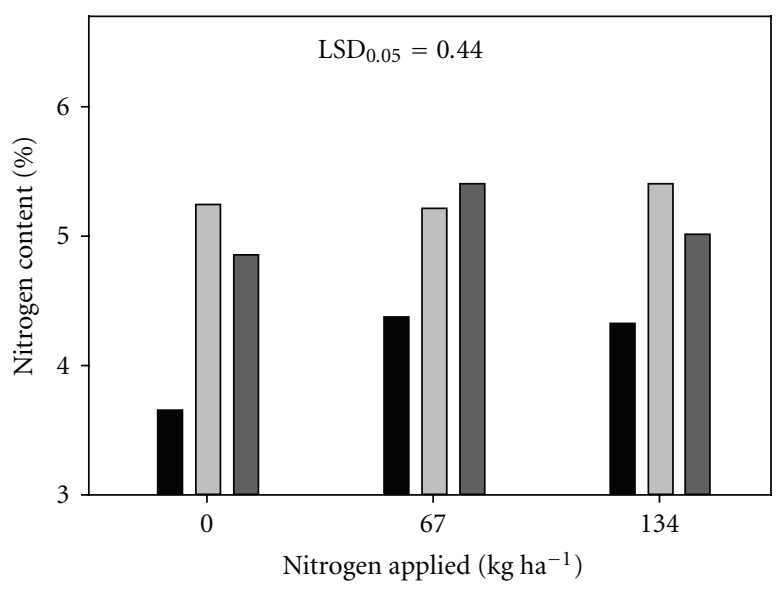

(a)

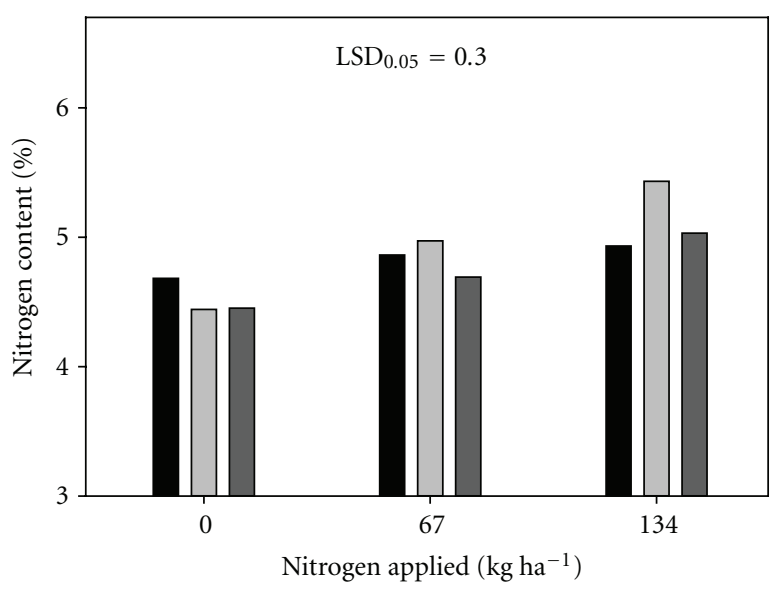

(b)

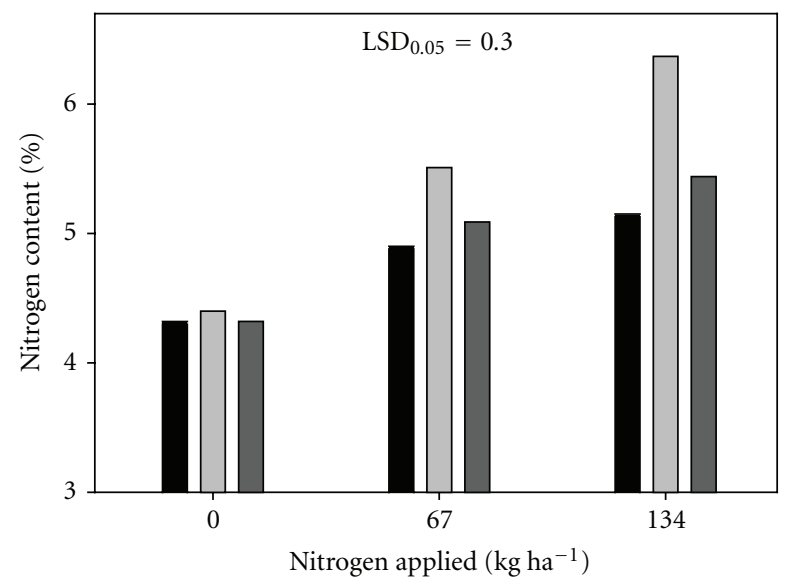

(c)

FIGURE 2: Nitrogen content of cotton leaf at flowering as affected by $\mathrm{N}$ rate and cover crop black bars no cover crop, light grey bars Austrian winter pea, dark grey bar hairy vetch, $(\mathrm{a})=2005,(\mathrm{~b})=2006$, and $(\mathrm{c})=2007$.

TABLE 2: $\delta \mathrm{N}^{15}$ abundance in plant residues before desiccation in 2005-2007.

\begin{tabular}{lccc}
\hline Cover crop & \multicolumn{3}{c}{$\delta \mathrm{N}^{15}$ abundance } \\
\hline None & 2005 & 2006 & 2007 \\
Austrian winter pea & 4.38 & 5.10 & 5.00 \\
Hairy vetch & 0.64 & 0.90 & 1.44 \\
LSD $_{0.05}$ year $\times$ cover crop & 1.05 & 1.33 & 1.33 \\
\hline
\end{tabular}

2006 and at planting following the third year of successive cover crop management, FDA was higher in Austrian pea with intermediate $\mathrm{N}$ than in plots maintained under hairy vetch. Stimulation of soil heterotrophic activity under cover crop management, especially leguminous cover crops, has been previously documented $[15,18]$. Both legumes elicited a reduction of soil $\mathrm{pH}$, with soils managed under Austrian pea initially having the lowest $\mathrm{pH}$ (Table 4). A reduction of soil $\mathrm{pH}$ under a hairy vetch and crimson clover cover crop has been reported in previous studies $[15,18]$.
The decrease in $\mathrm{pH}$ can be attributable to nitrification of ammonium released from decomposing legume plant tissue.

In all treatments, soil TNC increased during the three year study. Soil from plots seeded with Austrian winter pea had significantly greater TNC compared to the no cover crop soils in all samples, while plots from hairy vetch only had greater TNC compared to no cover crop soils in the 2007 at planting sample. A significant effect of $\mathrm{N}$ fertilizer was observed with greater $\mathrm{N}$ accumulation in soils receiving the higher $\mathrm{N}$ fertilizer rates. In the no cover crop controls there was an overall increase in TNC, most likely due to maintaining crop residues on the soil surface under reduced tillage management. The increases in soil TNC under hairy vetch occurred much slower than that of a study conducted on this site under soybean production [15]. However the magnitude of enhanced TNC accumulation in soil in plots from Austrian winter pea is greater than that attributed to other legumes; in the case of Austrian winter pea there was an additive effect of $\mathrm{N}$ fertilization on total soil $\mathrm{N}$ pools that was not observed for the no cover crop or hairy vetch plots in 2006 and 2007 (data not shown). 
TABLE 3: Yearly estimates of total biological N fixed in above ground legume cover crop biomass before desiccation in $2005-2007$.

\begin{tabular}{|c|c|c|c|}
\hline \multirow{2}{*}{ Cover crop } & \multicolumn{3}{|c|}{ Total $\mathrm{N}_{2}$ fixed, $\mathrm{kg} / / \mathrm{ha}$} \\
\hline & 2005 & 2006 & 2007 \\
\hline \multicolumn{4}{|l|}{ Austrian winter pea } \\
\hline $0 \mathrm{~N}$ & 92 & 124 & 146 \\
\hline $67 \mathrm{~N}, \mathrm{~kg} / \mathrm{ha}$ & 149 & 117 & 178 \\
\hline $134 \mathrm{~N}, \mathrm{~kg} / \mathrm{ha}$ & 151 & 114 & 177 \\
\hline \multicolumn{4}{|l|}{ Hairy vetch } \\
\hline $0 \mathrm{~N}$ & 96 & 68 & 165 \\
\hline $67 \mathrm{~N}, \mathrm{~kg} / \mathrm{ha}$ & 103 & 109 & 161 \\
\hline $134 \mathrm{~N}, \mathrm{~kg} / \mathrm{ha}$ & 67 & 85 & 133 \\
\hline $\mathrm{LSD}_{0.05}$ year $\times$ cover crop $\times \mathrm{N}$ & & 43 & \\
\hline
\end{tabular}

TABLE 4: Effect of Austrian winter pea and hairy vetch on soil properties in 2005-2007. ${ }^{\text {a }}$

\begin{tabular}{|c|c|c|c|c|c|}
\hline \multirow[t]{2}{*}{ Cover crop } & $04 / 24 / 05$ & $05 / 23 / 05$ & $04 / 27 / 06$ & $05 / 16 / 06$ & $04 / 30 / 07$ \\
\hline & \multicolumn{5}{|c|}{ Fluorescein diacetate hydrolytic activity, mmol/kg soil/h } \\
\hline None & $121 \mathrm{a}$ & $109 \mathrm{a}$ & $68 \mathrm{a}$ & $80 \mathrm{c}$ & $84 \mathrm{c}$ \\
\hline Austrian winter pea & $79 b$ & $108 \mathrm{a}$ & $73 \mathrm{a}$ & $133 \mathrm{a}$ & $130 \mathrm{a}$ \\
\hline \multirow[t]{2}{*}{ Hairy vetch } & $91 \mathrm{~b}$ & $99 \mathrm{a}$ & $75 \mathrm{a}$ & $100 \mathrm{~b}$ & $100 \mathrm{~b}$ \\
\hline & \multicolumn{5}{|c|}{$\mathrm{pH}$} \\
\hline None & $6.35 \mathrm{a}$ & $6.22 \mathrm{a}$ & $6.35 \mathrm{a}$ & $6.22 \mathrm{a}$ & $6.04 \mathrm{a}$ \\
\hline Austrian winter pea & $5.82 \mathrm{c}$ & $5.91 \mathrm{~b}$ & $5.85 \mathrm{c}$ & $5.91 \mathrm{~b}$ & $5.60 \mathrm{~b}$ \\
\hline \multirow[t]{2}{*}{ Hairy vetch } & $6.10 \mathrm{~b}$ & $6.04 \mathrm{ab}$ & $6.12 \mathrm{~b}$ & $5.96 \mathrm{~b}$ & $5.66 \mathrm{~b}$ \\
\hline & \multicolumn{5}{|c|}{ Total $\mathrm{N}$ content, $\mathrm{g} / \mathrm{kg}$ soil } \\
\hline None & $0.75 \mathrm{~b}$ & $1.0 \mathrm{~b}$ & $0.92 \mathrm{~b}$ & $0.92 \mathrm{~b}$ & $1.03 \mathrm{c}$ \\
\hline Austrian winter pea & $0.82 \mathrm{a}$ & $1.15 \mathrm{a}$ & $1.08 \mathrm{a}$ & $1.28 \mathrm{a}$ & $1.62 \mathrm{a}$ \\
\hline \multirow[t]{2}{*}{ Hairy vetch } & $0.73 \mathrm{~b}$ & $1.07 \mathrm{ab}$ & $1.02 \mathrm{ab}$ & $1.17 \mathrm{~b}$ & $1.34 \mathrm{~b}$ \\
\hline & \multicolumn{5}{|c|}{ Total organic carbon content, $\mathrm{g} / \mathrm{kg}$ soil } \\
\hline None & $9.0 \mathrm{a}$ & $8.8 \mathrm{a}$ & $9.2 \mathrm{~b}$ & $9.9 \mathrm{c}$ & $10.5 \mathrm{c}$ \\
\hline Austrian winter pea & $9.3 \mathrm{a}$ & $9.3 \mathrm{a}$ & $10.8 \mathrm{a}$ & $13.1 \mathrm{a}$ & $16.1 \mathrm{a}$ \\
\hline Hairy vetch & $8.5 \mathrm{a}$ & $9.4 \mathrm{a}$ & $10.2 \mathrm{ab}$ & $11.6 \mathrm{~b}$ & $13.5 \mathrm{~b}$ \\
\hline
\end{tabular}

${ }^{a}$ Means followed by the same letter within a column for the same sampling date do not differ at the $95 \%$ confidence level.

Total OC likewise increased in all treatments over time, again in response to reduced tillage as discussed with soil TNC (Table 4). By planting in 2007 the TOC of the upper $5 \mathrm{~cm}$ was $56 \%$ higher in Austrian winter pea compared to no cover. Total organic carbon accumulation in hairy vetch occurred at a lower rate, with a $30 \%$ greater TOC in hairy vetch compared to no cover in 2007. The leguminous cover crops, especially Austrian winter pea, decreased soil $\mathrm{pH}$ (Table 4). This effect was observed in the spring of the first year of the study and the same magnitude of acidity maintained thereafter.

Extractable soil nitrate was determined for all years the day of planting and before fertilization (Table 5). In the first year there was no effect of cover crop on extractable soil nitrate- $\mathrm{N}$, and there was minimal decomposition of surface residues (Table 1). However in 2006 and 2007, there was a significant interaction of cover crop and fertilization rate on residual soil nitrate levels at planting (Table 5). The highest nitrate levels were associated with Austrian winter pea plots with incremental gains associated with increasing $\mathrm{N}$ application. In the final year, the highest level of fertilization increased extractable soil nitrate by 34 and $47 \%$ in no cover and hairy vetch, while the highest $\mathrm{N}$ rate elicited a $137 \%$ increase in extractable $\mathrm{N}$ in Austrian winter pea.

3.3. Cotton Foliar $N$ Content, Yield, and Economics. Foliar $\mathrm{N}$ content at mid-flowering stage of cotton is presented in Figure 2. A significant incremental increase in $\mathrm{N}$ content in response to $\mathrm{N}$ fertilization was observed in 2006 and 2007, while only the two highest $\mathrm{N}$ rates increased $\mathrm{N}$ content in 2005. The leguminous cover crops increased $\mathrm{N}$ content only in 2005 and 2007, with the highest $\mathrm{N}$ content associated with Austrian winter pea in three of the four enhanced samples. A significant fertilizer by cover crop interaction was observed in 2006 and 2007, with incremental increases in foliar $\mathrm{N}$ content of cotton grown on cover crop plots in response to increasing $\mathrm{N}$ rate. The elevated $\mathrm{N}$ concentrations found in the leaf samples from all $\mathrm{N}$ fertilized cover crop plots may be considered excessive. At this stage of reproductive growth a 
TABLE 5: Interaction of cover crop and N rate on soil nitrate present at planting in 2005, 2006, and 2007.

\begin{tabular}{|c|c|c|c|c|}
\hline \multirow[t]{2}{*}{ Year } & \multirow{2}{*}{$\begin{array}{c}\mathrm{N} \text { applied } \\
\mathrm{kg} / \mathrm{ha}\end{array}$} & \multicolumn{3}{|c|}{ Cover crop } \\
\hline & & None & Austrian winter pea & Hairy vetch \\
\hline & & & $\mathrm{mg} \mathrm{NO}-\mathrm{N} / \mathrm{kg} \mathrm{sc}$ & \\
\hline \multirow{4}{*}{2005} & 0 & 20 & 21 & 21 \\
\hline & 67 & 21 & 22 & 22 \\
\hline & 134 & 21 & 21 & 21 \\
\hline & 0 & 27 & 31 & 27 \\
\hline \multirow[t]{2}{*}{2006} & 67 & 31 & 55 & 39 \\
\hline & 134 & 34 & 98 & 51 \\
\hline \multirow{3}{*}{2007} & 0 & 38 & 45 & 42 \\
\hline & 67 & 44 & 63 & 55 \\
\hline & 136 & 51 & 107 & 62 \\
\hline $\mathrm{LSD}_{0.05}$ year $\times$ cover crop $\times \mathrm{N}$ & & & 5 & \\
\hline
\end{tabular}

TABle 6: Effect of cover crop, and N fertilizer on seed cotton yield in 2005-2007.

\begin{tabular}{|c|c|c|c|}
\hline \multirow[b]{2}{*}{ Treatments } & \multicolumn{3}{|c|}{ Seed cotton, kg/ha } \\
\hline & 2005 & 2006 & 2007 \\
\hline \multicolumn{4}{|l|}{ Cover crop } \\
\hline None & 3597 & 4019 & 2624 \\
\hline Austrian winter pea & 3095 & 4407 & 2976 \\
\hline Hairy vetch & 3028 & 4269 & 2846 \\
\hline $\mathrm{LSD}_{0.05}$ & 475 & ns & ns \\
\hline \multicolumn{4}{|l|}{$\mathrm{N}$ rate, $\mathrm{kg} / \mathrm{ha}$} \\
\hline 0 & 3171 & 3883 & 2460 \\
\hline 67 & 3216 & 4141 & 2871 \\
\hline 134 & 3331 & 4671 & 3114 \\
\hline $\mathrm{LSD}_{0.05}$ & ns & 515 & 431 \\
\hline \multicolumn{4}{|l|}{ Interactions } \\
\hline None $\times 0 \mathrm{~N}$ & 3263 & 3554 & 1712 \\
\hline None $\times 67 \mathrm{~N}$ & 3704 & 4060 & 2659 \\
\hline None $\times 134 \mathrm{~N}$ & 3823 & 4442 & 3499 \\
\hline Austrian winter pea $\times 0 \mathrm{~N}$ & 3198 & 4006 & 2827 \\
\hline Austrian winter pea $\times 67 \mathrm{~N}$ & 3031 & 4178 & 3106 \\
\hline Austrian winter pea $\times 134 \mathrm{~N}$ & 3053 & 5034 & 2992 \\
\hline Hairy vetch $\times 0 \mathrm{~N}$ & 3053 & 4087 & 2838 \\
\hline Hairy vetch $\times 67 \mathrm{~N}$ & 2913 & 4184 & 2846 \\
\hline Hairy vetch $\times 134 \mathrm{~N}$ & 3117 & 4534 & 2851 \\
\hline $\mathrm{LSD}_{0.05}$ & 525 & ns & 805 \\
\hline
\end{tabular}

level of sufficient $\mathrm{N}$ is 3.0 to $4.5 \%$, and above $4.5 \%$ is excessive $[19,20]$.

In the three years of the study, there was a different yield response to cover crops, and $\mathrm{N}$ fertilization (Table 6). Cotton plant population was not affected by cover crop or $\mathrm{N}$ rates and averaged 83,000 plants/ha in all three years (data not shown); hence plant density was not a factor affecting yield. In the first year of the study both leguminous cover crops significantly decreased seed cotton yields; however, no response to $\mathrm{N}$ fertilization was observed. In the second year, no significant effect of cover crop was observed, but seed cotton yield significantly increased at the highest $\mathrm{N}$ rate. Similarly, in the third year of the study, seed cotton yield was increased with increased $\mathrm{N}$ rate, but unaffected by cover crops. In 2006 and 2007, there was a significant effect of $\mathrm{N}$ fertilization, with the highest rate yielding significantly greater seed cotton compared to no fertilizer. Analysis of variance of seed cotton yield indicated a significant interaction between cover crop and $\mathrm{N}$ rate in two (2005 and 2007) of three years. In 2005, N at 67 and $134 \mathrm{~kg} / \mathrm{ha}$ applied in no cover crop produced higher seed cotton yield than in Austrian winter pea and hairy vetch. In 2007 , no N plots in both cover crops yielded higher than no $\mathrm{N}$ plots in no cover crop. However, seed cotton yields either 
at $67 \mathrm{~kg} / \mathrm{ha} \mathrm{N}$ or $134 \mathrm{~kg} / \mathrm{ha} \mathrm{N}$ were similar regardless of cover crops. Essentially, in the no cover crop plots, an incremental yield gain was observed in response to increasing $\mathrm{N}$ fertilizer. All Austrian winter pea and hairy vetch plots, regardless of $\mathrm{N}$ fertilization, yielded greater than the no cover crop, no $\mathrm{N}$ plots. Furthermore, all Austrian winter and hairy vetch plots regardless of $\mathrm{N}$ rates were not significantly different than the no cover, $134 \mathrm{~kg} / \mathrm{ha} \mathrm{N}$.

Excessive $\mathrm{N}$ availability can contribute to loss in cotton yield due to a delay in maturity, increased potential for boll rot and regrowth following defoliation. This may have been the case in both legume cover crops. In addition the mineralization of $\mathrm{N}$ from cover crop residues may not come in a timely manner to support sustaining higher cotton yields. When cotton follows corn fertilized with a high $\mathrm{N}$ rate in Louisiana, the elevated residual soil $\mathrm{N}$ can cause an overall loss in cotton productivity unless fertilization rates for cotton are also reduced [21]. Thus, growers seeking to maximize economic returns would find the cost of establishing legume crops unable to offset any possible savings in $\mathrm{N}$ fertilizer costs. Application of $\mathrm{N}$ accounted for 70 and 140 dollars/ha, while cost of establishment for no cover, Austrian winter pea, and hairy vetch was 43, 215 and 334 dollars/ha in 2007. The seeding rate of $30 \mathrm{~kg} / \mathrm{ha}$ was similar to that used by Schomberg et al. [8]. To fully assess the contributions of leguminous cover crops on $\mathrm{N}$ fertilizer replacement it would be desirable to have additional increments of $\mathrm{N}$ fertilization.

The interaction of legume cover crop and $\mathrm{N}$ fertilization observed in this Mississippi study differed substantially from studies in Western Tennessee [7], where hairy vetch provided sufficient $\mathrm{N}$ to maximize yields with less than half the $\mathrm{N}$ fertilization rate, especially under no-tillage conditions. However, the initial depression in cotton yield in response to legume cover crops in these studies is similar to the depression in cotton yield in studies conducted in the sandy soils of South Carolina [22] and Georgia [8]. This was a three-year study with the first year totally unresponsive to $\mathrm{N}$ inputs. However, considering the performance of cover crops (Austrian winter pea and hairy vetch) in the last two years of the study, leguminous cover crops offer potential in sustainable low-input production systems for no-till cotton. In terms of developing sustainable land use and improving soil quality components of improved organic carbon and biologically derived $\mathrm{N}$, there are many benefits of a leguminous cover crop system as suggested by others [6]. It is possible to achieve comparable yields to chemical fertilizer; however, there is a degree of uncertainty in achieving a maximum economic advantage using a leguminous cover crop system for cotton production in the Mississippi Delta.

\section{Acknowledgments}

The authors thank Efren Ford, Terry Newton, and Albert Tidwell for technical assistance in field work. Mention of trade names or commercial products in this paper is solely for the purpose of providing specific information and does not imply recommendation or endorsement by the U.S. Department of Agriculture.

\section{References}

[1] D. W. Reeves, "Cover crops and rotations," in Advances in Soil Science: Crop Residue Management, J. L. Hatfield and B. A. Stewart, Eds., pp. 125-172, Lewis Publication, Boca Raton, Fla, USA, 1994.

[2] M. S. Reiter, D. W. Reeves, C. H. Burmester, and H. A. Torbert, "Cotton nitrogen management in a high-residue conservation system: cover crop fertilization," Soil Science Society of America Journal, vol. 72, no. 5, pp. 1321-1329, 2008.

[3] C. H. Koger and K. N. Reddy, "Effects of a hairy vetch (Vicia villosa) cover crop or a weedy fallow and banded herbicides on weed dynamics, grain yield, and economic returns in corn (Zea mays)," Journal of Sustainable Agriculture, vol. 26, pp. 107-124, 2005.

[4] T. M. Reinbott, S. P. Conley, and D. G. Blevins, "No-tillage corn and grain sorghum response to cover crop and nitrogen fertilization," Agronomy Journal, vol. 96, no. 4, pp. 1158-1163, 2004.

[5] I. Rochester and M. Peoples, "Growing vetches (Vicia villosa Roth) in irrigated cotton systems: inputs of fixed N, N fertiliser savings and cotton productivity," Plant and Soil, vol. 271, no. 1-2, pp. 251-264, 2005.

[6] C. Tonitto, M. B. David, and L. E. Drinkwater, "Replacing bare fallows with cover crops in fertilizer-intensive cropping systems: a meta-analysis of crop yield and N dynamics," Agriculture, Ecosystems and Environment, vol. 112, no. 1, pp. 58-72, 2006.

[7] J. A. Larson, R. K. Roberts, E. C. Jaenicke, and D. D. Tyler, "Profit-maximizing nitrogen fertilization rates for alternatives tillage and winter cover systems," Journal of Cotton Science, vol. 5, no. 3, pp. 156-168, 2001.

[8] H. H. Schomberg, R. G. McDaniel, E. Mallard, D. M. Endale, D. S. Fisher, and M. L. Cabera, "Conservation tillage and cover crop influences on cotton production on a Southern U.S. coastal plain soil," Agronomy Journal, vol. 98, pp. 1247-1256, 2006.

[9] K. N. Reddy and J. C. Boykin, "Weed control and yield comparisons of twin- and single-row glyphosate-resistant cotton production systems," Weed Technology, vol. 24, no. 2, pp. 95-101, 2010.

[10] M. B. Peoples and D. F. Herridge, "How much nitrogen is fixed by legumes?" Agricultural Science, vol. 3, pp. 24-29, 1990.

[11] M. B. Peoples, R. M. Boddey, and D. F. Herridge, "Quantification of nitrogen fixation," in Nitrogen Fixation at the Millennium, G. J. Leigh, Ed., pp. 357-389, Elsevier Science, Amsterdam, The Netherlands, 2002.

[12] D. A. Cataldo, M. Haroon, L. E. Schrader, and V. L. Youngs, "Rapid colorimetric determination of nitrate in plant tissue by nitration of salicylic acid," Communication Soil Science Plant Analysis, vol. 6, pp. 71-80, 1975.

[13] R. M. Zablotowicz, R. E. Hoagland, W. J. Staddon, and M. A. Locke, "Effects of $\mathrm{pH}$ on chemical stability and de-esterification of fenoxaprop-ethyl by purified enzymes, bacterial extracts, and soils," Journal of Agricultural and Food Chemistry, vol. 48, no. 10, pp. 4711-4716, 2000.

[14] R. M. Zablotowicz, M. A. Locke, and L. A. Gaston, "Tillage and cover effects on soil microbial properties and fluometuron degradation," Biology and Fertility of Soils, vol. 44, no. 1, pp. 27-35, 2007.

[15] R. M. Zablotowicz, K. N. Reddy, M. A. Weaver et al., "Cover crops, tillage and glyphosate effects on soil biology, chemistry and soybean yield," Environmental Research Journal, vol. 4, pp. 227-251, 2010. 
[16] H. H. Janzen and S. M. McGinn, "Volatile loss of nitrogen during decomposition of legume green manure," Soil Biology and Biochemistry, vol. 23, no. 3, pp. 291-297, 1991.

[17] H. C. Pringle III and M. W. Ebelhar, A Weather Summarization Tool for Data Comparisons, Mississippi Agricultural and Forestry Experiment Station Information Bulletin 444, Mississippi State University, Stoneville, Miss, USA, 2009.

[18] K. N. Reddy, R. M. Zablotowicz, M. A. Locke, and C. H. Koger, "Cover crop, tillage, and herbicide effects on weeds, soil properties, microbial populations, and soybean yield," Weed Science, vol. 51, no. 6, pp. 987-994, 2003.

[19] T. J. Gerik, D. M. Oosterhuis, and H. A. Torbert, "Managing cotton nitrogen supply," Advances in Agronomy, vol. 64, pp. 115-147, 1998.

[20] W. E. Sabbe and A. J. MacKenzie, "Plant analysis as an aid to cotton fertilization," in Soil Testing and Plant Analysis, L. M. Walsh and J. D. Beaton, Eds., pp. 299-313, Soil Science Society of America, Madison, Wis, USA, 1980.

[21] D. J. Boquet, B. S. Tubaña, H. J. Mascagni Jr., M. Holman, and S. Hague, "Cotton yield responses to fertilizer nitrogen rates in a cotton-corn rotation," Agronomy Journal, vol. 101, no. 2, pp. 400-407, 2009.

[22] P. J. Bauer and W. J. Busscher, "Winter cover and tillage influences on coastal plain cotton production," Journal of Production Agriculture, vol. 9, no. 1, pp. 50-54, 1996. 


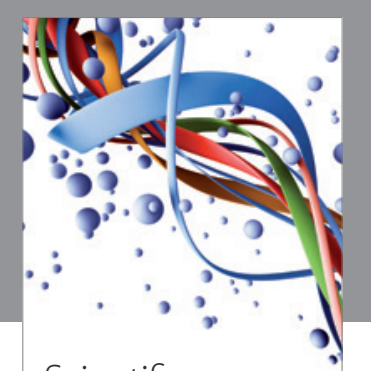

Scientifica
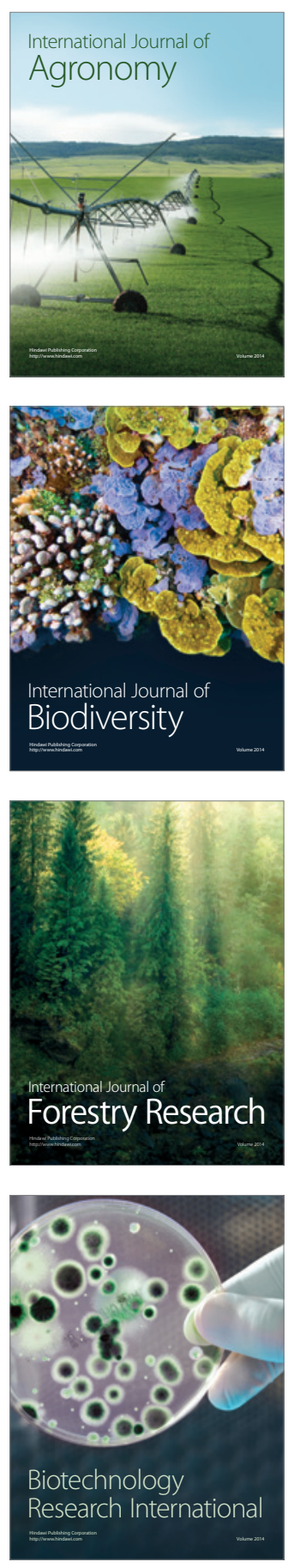
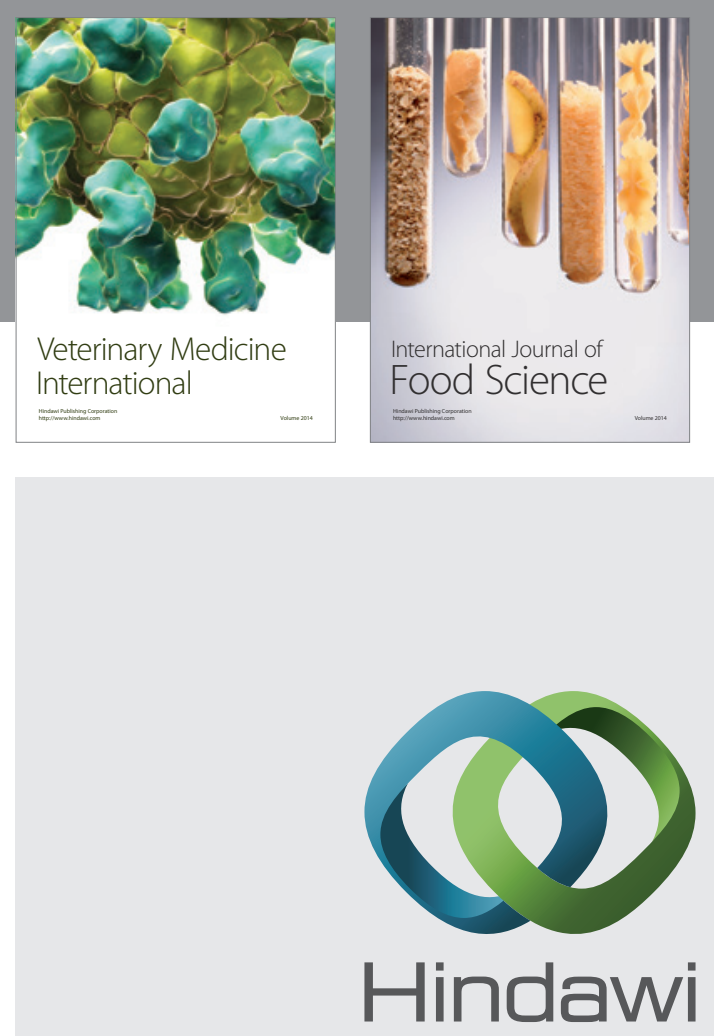

Submit your manuscripts at

http://www.hindawi.com
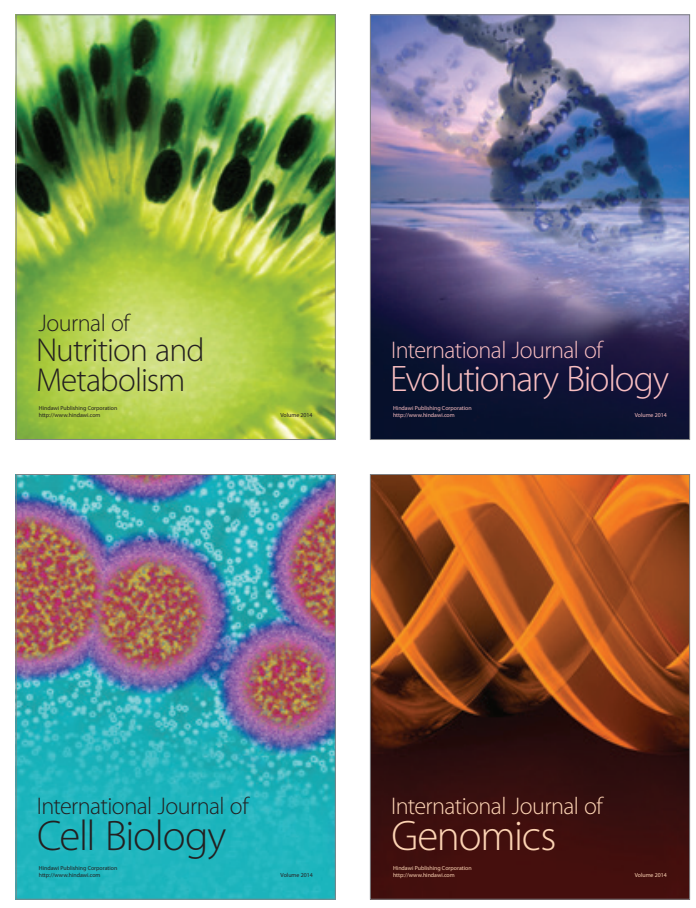
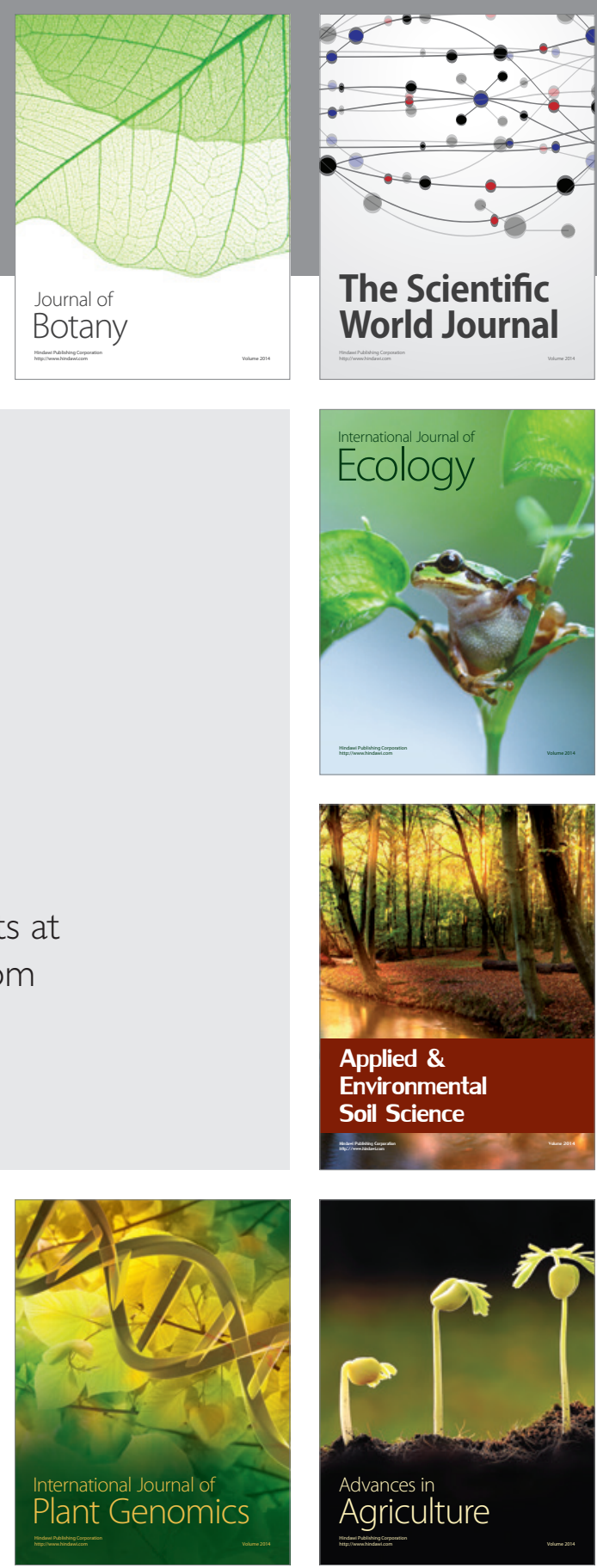

The Scientific World Journal
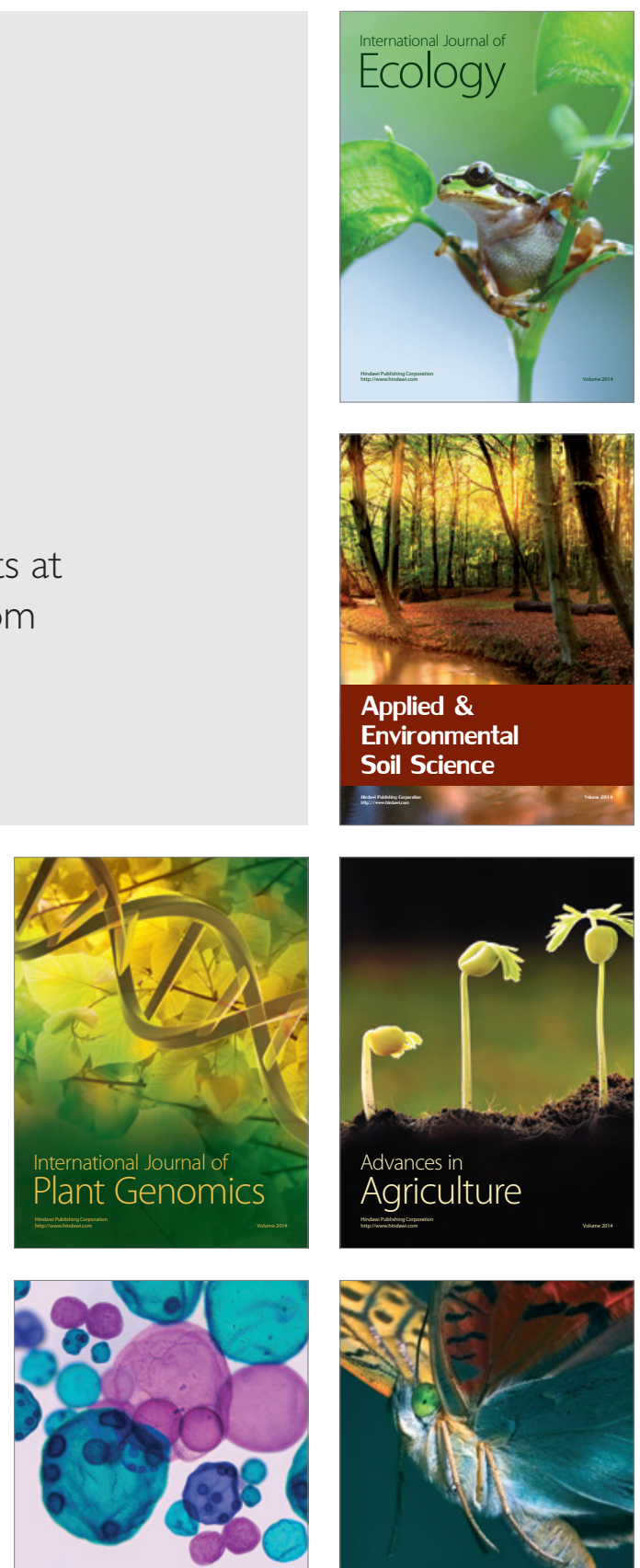

International Journal of Microbiology

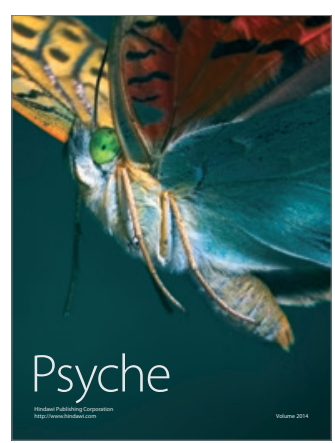

